\title{
Misruling the Masses: The Consequences of Cracking Down in Kyrgyzstan
}

\author{
Charles Sullivan* \\ Department of Political Science and International Relations, Nazarbaev University, Nur-Sultan, Kazakhstan \\ ${ }^{\star}$ Corresponding author. Email: charles.sullivan@nu.edu.kz
}

\begin{abstract}
Can nondemocratic leaders initiate a crackdown against mass protesters and suffer little in the way of political-reputational costs? In conceptualizing a "crackdown" as a government-orchestrated violent restriction of civil society involving the killing of civilians, this article analyzes how the use of force is perceived by ordinary citizens when their government represses a portion of the populace. In analyzing the findings of a 2016 survey that gauges contemporary attitudes toward the overthrow of presidents Askar Akaev (in 2005) and Kurmanbek Bakiev (in 2010), this article argues that Kyrgyzstanis evaluate the Bakiev administration more negatively than they do the Akaev administration because of the former's resort to forceful measures in attempting to quell mass protesters in April 2010. Such findings imply that nondemocratic leaders who employ force against mass protesters incur significant political-reputational costs, irrespective as to whether the wider public views the mass protests as legitimate or not.
\end{abstract}

Keywords: Kyrgyzstan; mass protests; Central Asia; authoritarianism; legitimacy

\section{Introduction}

All nondemocratic leaders utilize coercion to some extent to maintain political order. Yet can such leaders brazenly repress mass protesters and get away with it? In analyzing the "Color Revolutions" of Serbia in 2000, Georgia in 2003, and Ukraine in 2004-2005, one common feature of the Bulldozer, Rose, and Orange revolutions concerned these governments' seeming inability or unwillingness to resort to brute force tactics to stave off regime change (McFaul 2005, 14-15). Some scholars contend that regime change occurred within these countries due to the absence of "highly institutionalized ruling parties," the underfunded and undisciplined nature of the ruling regimes' "coercive apparatuses," significant levels of economic privatization, and "linkages" to the West (Way 2008). In contrast, others have argued that "international donor support" and an "electoral model" played a role in terms of exposing the corrupt nature of these governments and issuing popular demands for regime change (Bunce and Wolchik 2006, 2009). Although it may seem as if the color revolutions are but a relic nowadays, perhaps they still retain significance. After all, a seemingly non-interrelated assortment of mass protests has recently taken place across the former Soviet Union region. In some instances, governments resorted to violence against mass protesters, going so far as shooting civilians in public squares. In cases such as Kyrgyzstan in 2010 and Ukraine in 2014, however, the employment of such violence (at the very least) failed to subdue the mass protests and arguably backfired to such an extent that it sparked the downfall of these governments and the flight of President Kurmanbek Bakiev to Belarus and Viktor Yanukovych to Russia, respectively. Such outcomes raise the following research question: Do nondemocratic leaders incur significant political-reputational costs for employing violence against mass protesters to stave off regime change? 
This article explores contemporary attitudes in Kyrgyzstan toward the overthrows of former presidents Askar Akaev in 2005 and Kurmanbek Bakiev in 2010 by reporting the findings of a computer-assisted telephone interviewing survey conducted across seven regions and two cities from June 30 to July 20,2016, and offering a tentative explanation for such popular sentiments. The survey results, which had 1,000 respondents, was carried out by a Kyrgyzstan-based subcontractor of the BRIF Research Group (headquartered in Almaty, Kazakhstan). Respondents ranged in ages from 30 to 89 years old, and approximately 91 percent identified as "Kyrgyz." Initially, this article highlights frequency distributions pertaining to popular opinions toward Akaev and Bakiev's administrations. Thereafter, cross tabulation analysis reveals the sentiments that Kyrgyzstanis who did not participate in the 2005 or 2010 protests harbor toward their former leaders. ${ }^{3}$ Overall, the main research findings in this article highlight that Kyrgyzstanis generally evaluate both the Akaev and Bakiev administrations unfavorably, but the latter is considerably more despised than its governing predecessor. Furthermore, even though the 2005 and 2010 protests lack widespread social support, the data set seemingly reveals that many Kyrgyzstanis look upon Bakiev unfavorably because of his willingness to use violence in the face of mass protests in April 2010. Such a finding implies that a nondemocratic ruler who institutes a crackdown will incur major politicalreputational costs as a result.

\section{Cracking Down}

Nondemocratic leaders utilize a variety of tactics to remain in power. Their playbook largely consists of lying, cheating, stealing, repressing, manipulating, deflecting blame, and/or occasionally killing anyone who stands in their way (Collier 2009). The academic literature further informs that some nondemocratic regimes are more stable than others. In particular, certain systems (in which elites come to power through armed struggle and administer via "single-party rule") are more likely to remain intact during difficult times because the elites build up networks with the local populace and fuse the party with the state apparatus, instead of relying on rent-seeking initiatives (Smith 2005). In addition, it is beneficial for nondemocratic leaders to institutionalize their power to a degree, so that elites (who within such a system will be afforded somewhat of a say in policy making) give their support (Gandhi and Przeworski 2007). In terms of analyzing the manner in which nondemocratic governments employ violence against civilians, the literature diverges along several paths. One direction focuses on the relationship between repression and radicalization. Some scholars posit that highly repressive governments are more likely to engender the rise of militant groups (McGlinchey 2005). A second direction emphasizes which types of nondemocratic regimes are most likely to engage in state-sponsored massacres. Accordingly, nondemocratic leaders who rely heavily on local security forces (or "armed government personnel") to ensure order and do not face "executive constraints" (thereby making it difficult for oppositionists to reliably bargain with them) are able to carry out atrocities (Colaresi and Carey 2008). Relatedly, when it comes to employing coercion "competitive authoritarian" regimes can make use of a variety of "high-intensity" and "low-intensity" strategies (Levitsky and Way 2010, 56-61). Yet what happens when people stand in defiance against a nondemocratic government? A third direction analyzes the dynamic between citizens and nondemocratic leaders when the former are able to organize and challenge the latter's claim to power. It has been argued that mass protesters are most likely to succeed in ousting a nondemocratic leader if they diversify their ranks and exhibit dissatisfaction with the government in a peaceful manner. Protests involving worker strikes, boycotts, public demonstrations, and a multiplicity of interest groups thus have a far better chance at succeeding than do oppositionists who make use of violent tactics. After all, the turn to violence plays into the hands of nondemocratic governments, which can justify the commission of their own coercive agents to utilize deadly force to preserve order (Chenoweth and Stephan 2014). But do nondemocratic leaders incur significant costs for employing violence against mass protesters contesting their authority? 
Protests constitute one aspect of civil society, in the sense that people who partake in them aspire to limit or contest the authority of the state in some manner. Civil society groups "seek from the state concessions, benefits, policy changes, relief, redress, or accountability" (Diamond 1994, 6).

In drawing upon this reference, a "crackdown" can be conceptualized as a governmentorchestrated violent restriction of civil society involving the killing of civilians, namely mass protesters. A crackdown, as defined here, represents a type of "high-intensity coercion" on account of that such an act of state-sponsored violence possesses "high visibility" and is designed to "target large numbers of people, well-known individuals, or major institutions" (Levitsky and Way 2010, 57). To be certain, nondemocratic governments facing mass protesters need not institute a crackdown. Perhaps though a government's decision to crack down is made in some instances because protesters turn violent to realize their aims? Assuming this occasionally happens, the distinction between mass protesters and mobs merits analysis. Accordingly, if a nondemocratic leader seeks to carry out a crackdown, then he or she will likely depict mass protesters as an unruly mob (perhaps by deploying provocateurs acting on behalf of the ruling regime into crowds of protesters for the purpose of stirring up trouble and inciting violence). Any mobilized group contesting governmental authority is thus likely to be portrayed by a nondemocratic government as uncivil, which in turn arguably justifies the leader's employment of repressive methods. But how can scholars objectively assess whether any mobilized group contesting governmental authority amounts to a legitimate social movement or a mob? Overall, it is difficult to differentiate between the two, in light of that mass protesters likely view themselves as legitimate (irrespective as to whether they resort to violence or not) while a nondemocratic government perceives them as illegitimate for challenging power. Meanwhile, ordinary people are likely to hold differing opinions toward groups contesting authority.

Of course, some scholars may be hesitant to label those who participated in the 2005 and 2010 revolutions in Kyrgyzstan as members of an unruly mob, but the fact remains that both Akaev and Bakiev were removed from power in an extraconstitutional manner. Furthermore, frequency distributions for a question included in the aforementioned 2016 computer-assisted telephone interviewing survey show that while a plurality of respondents (34 percent) perceived both the 2005 and 2010 protests to be legitimate, a substantial portion (26 percent) considered both illegitimate. Meanwhile, 21 percent did not offer any opinion (see table 1 ). ${ }^{4}$ Bearing this in mind, this article seeks to uncover how Kyrgyzstani citizens evaluate the attempted crackdowns by their former political leaders against their fellow countrymen. Hence, in touching upon the complexities involved in determining whether a gathered assembly of mass protesters amounts to a legitimate social movement or an illegitimate

Table 1. Contemporary popular attitudes on the legitimacy of the 2005 and 2010 protests in Kyrgyzstan.

\begin{tabular}{lcc}
\hline Responses & Frequency & Percent \\
\hline $\begin{array}{l}\text { I believe that the mass protests against Akaev's rule were legitimate in nature but } \\
\text { the mass protests against Bakiev's rule were illegitimate in nature. }\end{array}$ & 101 & 10.0 \\
\hline $\begin{array}{l}\text { I believe that the mass protests against Bakiev's rule were legitimate in nature } \\
\text { but the mass protests against Akaev's rule were illegitimate in nature. }\end{array}$ & 83 & 8.3 \\
\hline $\begin{array}{l}\text { I believe that the mass protests against both Akaev's rule and Bakiev's rule } \\
\text { were legitimate in nature. }\end{array}$ & 343 & 34.2 \\
\hline $\begin{array}{l}\text { I believe that the mass protests against both Akaev's rule and Bakiev's rule } \\
\text { were illegitimate in nature. }\end{array}$ & 259 & 25.8 \\
\hline I have no opinion on this issue. & 210 \\
\hline Hard to say. & 7 & 20.9 \\
\hline Refusal. & 1 & 0.7 \\
\hline $\mathrm{N}$ & 1004 & 100.0 \\
\hline
\end{tabular}


unruly mob, for the purposes of this article it is assumed that (1) nondemocratic leaders are likely to perceive, as well as collectively depict, such protesters as members of an unruly mob, while (2) ordinary people are likely to hold differing views with regards to the legitimacy and behavior of mobilized social groups which seek to openly contest political authority.

\section{Akaev, Bakiev, and the Revolutions}

Askar Akaev (1990-2005) and Kurmanbek Bakiev (2005-2010) both presided over semiauthoritarian political systems. However, they lacked a combination of institutions, resources, and skills to remain in power indefinitely. Generally speaking, political contestation flourishes on occasion within semi-authoritarian systems because elites seek to manipulate governing institutions for their own benefit. Furthermore, such "hybrid regimes" (Diamond 2002) possess a "competitive authoritarian" character since oppositionists are able to exert some influence (Levitsky and Way 2002). Regimes which can be classified as such are therefore vulnerable to bouts of political turmoil because inefficient governance is the norm while a vocal opposition aspires to further the process of "breathing democratic life into the bones of formal representative institutions" (Schedler 2010, 78). Bearing this in mind, the manner in which Akaev's tenure in office ended substantially differs from that of Bakiev.

In analyzing the collapse of Akaev's "soft authoritarian" regime, Edward Schatz $(2009,213-217)$ argues that the former president's poor managerial skills (as evidenced by his ineptitude at "shoring up support" and "narrowing" of a "patronage base"), limited access to resources, and inability to bring the local media and opposition to a heel contributed to his downfall. All of these factors arguably set the stage for the Tulip revolution. That said, the trigger behind Akaev's overthrow in the spring of 2005 was rooted in "localism." According to Scott Radnitz (2006, 134-139), in response to the February 2005 parliamentary elections losing candidates activated their clientelistic networks, forged a temporary alliance, tapped into popular frustrations, and collectively rose up against Akaev. Relatedly, Henry Hale (2005, 157-158) posits that since Akaev did not seek to amend Kyrgyzstan's constitution to stay on as president for a third term, his "lame-duck" status rendered him vulnerable to overthrow. ${ }^{5}$ It is important to highlight the elite-centric nature of the Tulip Revolution, for Eric McGlinchey (2011, 96-100) contends that Akaev's failure to dole out economic rents to other powerbrokers in an equitable fashion (particularly after the opening of the US airbase at Manas International Airport) severely undercut the president's ability to govern effectively. ${ }^{6}$ Furthermore, Akaev arguably did not put up much of a fight when mass protests erupted in the spring of 2005 (or if he did try to quell the mass protests then his crackdown was sporadic and muted in nature). In the past local authorities had demonstrated a willingness to employ force to some extent, such as in Aksy in 2002. The resort to brute force tactics in this instance, however, sparked anti-government protests (Radnitz 2005). Hence, in 2005 when the mass protesters reached the capital, Akaev seemingly fled in haste. Radnitz (2006, 134-137) claims that while Akaev had issued an order to evict protesters from the main administrative building in Jalal-Abad and arrest the leaders, he instructed local security "not to use force" against protesters in Bishkek several days later. Thus, in assessing the Tulip Revolution the argument can be made that "in the final reckoning ... Akaev's failures and personal fears played the primary role in the regime's collapse" (Hill and Jones 2006, 115).

In contrast, Bakiev's overthrow was brought about by a series of factors. In a general sense, Bakiev's attempts to suffocate the opposition, gross mismanagement of the economy, and corrupt governing style spurred his downfall (Collins 2011, 153-156). ${ }^{7}$ In addition, public outrage against deteriorating services (namely electricity) combined with Bakiev's authoritarian governing style and mismanagement of public "hydroenergy" concerns facilitated the 2010 revolution (Wooden 2014). That said, it is important to emphasize that Russia also expedited Bakiev's downfall on account of the president's failure to make good on a promise to shutter the US military installation at Manas in return for Kyrgyzstan's receipt of a generous financial aid package from Moscow (Collins 2011, 156). The event that sparked the 2010 protests concerned a jolting price hike in electricity resulting from Russia's cessation of subsidized fuel (Cooley 2010, 302-304). Unlike the 
Tulip Revolution, Bakiev's overthrow also shook Kyrgyzstan's fragile political system. Following his ouster in April (which involved scores of civilian deaths), supporters of the deposed president in the south initiated a failed counter-coup in May. Shortly thereafter, ethnic violence (which may have been orchestrated by individuals in furtherance of discrediting Kyrgyzstan's newly installed provisional government and mostly involved Kyrgyz attacking Uzbeks) gripped the south in June, resulting in many deaths, the destruction of properties, mass human flight, economic downturn, and a heightened sense of social polarization (Collins 2011, 156, 159-161).

In observing frequency distributions of several survey questions, it is instructive to discover what ordinary Kyrgyzstanis think about Akaev and Bakiev today. Table 2 lists the results of a survey question concerning whether Kyrgyzstani citizens believe that the 2005 and/or 2010 protests were "orchestrated or sponsored by foreign states." Results show a nearly even split between those who think that both were facilitated by foreign states, those who believe that neither were facilitated by foreign states, and those who do not express any opinion. ${ }^{8}$ In turning to popular attitudes toward Akaev and/or Bakiev's attempts to suppress the 2005 and 2010 protests, results reveal a high degree of contempt for Bakiev due to his use of (what respondents deemed to be) "excessive force" (see table 3). Accordingly, a very substantial plurality (approximately 43 percent) opined that while Akaev did not resort to excessive measures in an attempt to quell mass protesters in 2005, Bakiev responded very harshly to mass protesters in $2010 .^{9}$

Were Akaev and Bakiev thought to be justified in resorting to forceful measures to stifle the protests against their administrations? In response to this survey question, a plurality (36 percent) felt that neither Akaev nor Bakiev had any cause to "employ force." Only a few respondents (7 percent) opined that Bakiev was justified to resort to forceful measures in 2010 while Akaev was not justified to do so in 2005, in comparison to more (18 percent) who felt that Akaev was justified to use force while Bakiev was not (see table 4). ${ }^{10}$ Herein lies an interesting finding, for a large plurality believes that Bakiev used "excessive force" while few think that the former president was justified in doing so. In contrast, Akaev does not fit within such a framework.

Judging by the results of some additional survey questions, Akaev and Bakiev are not held in high regard by their fellow countrymen. Bakiev, however, is disliked considerably more so than is Akaev. In response to a survey question concerning the apportionment of blame upon Akaev and/or Bakiev in regards to "the various domestic troubles facing the country today," a majority (53 percent) opined that both are "largely to blame" (see table 5). ${ }^{11}$ In response to another survey question

Table 2. Contemporary popular attitudes on foreign meddling in the 2005 and 2010 protests in Kyrgyzstan.

\begin{tabular}{lcc}
\hline Responses & Frequency & Percent \\
\hline $\begin{array}{l}\text { I believe that the mass protests against Akaev's rule were orchestrated or sponsored by foreign } \\
\text { states but I do not believe that the mass protests against Bakiev's rule were orchestrated or } \\
\text { sponsored by foreign states. }\end{array}$ & 56.6 \\
\hline $\begin{array}{l}\text { I believe that the mass protests against Bakiev's rule were orchestrated or sponsored by } \\
\text { foreign states but I do not believe that the mass protests against Akaev's rule were } \\
\text { orchestrated or sponsored by foreign states. }\end{array}$ & 130 & 13.0 \\
\hline $\begin{array}{l}\text { I believe that the mass protests against Akaev's rule and Bakiev's rule were orchestrated or } \\
\text { sponsored by foreign states. }\end{array}$ & 265 & 26.4 \\
\hline $\begin{array}{l}\text { I do not believe that the mass protests against either Akaev's rule or Bakiev's rule were } \\
\text { orchestrated or sponsored by foreign states. }\end{array}$ & 266 \\
\hline I have no opinion on this issue. & 26.5 \\
\hline Hard to say. & 274 & 27.3 \\
\hline N & 12 & 1.2 \\
\hline
\end{tabular}


Table 3. Contemporary popular attitudes on the use of excessive force by leaders in 2005 and 2010 in Kyrgyzstan.

\begin{tabular}{lcc}
\hline Responses & Frequency & Percent \\
\hline $\begin{array}{l}\text { I believe that Akaev used excessive force in attempting to suppress protesters in } 2005 \text { but } \\
\text { Bakiev did not use excessive force in attempting to suppress protesters in 2010. }\end{array}$ & 58.8 \\
\hline $\begin{array}{l}\text { I believe that Bakiev used excessive force in attempting to suppress protesters in } 2010 \text { but } \\
\text { Akaev did not use excessive force in attempting to suppress protesters in 2005. }\end{array}$ & 427 \\
\hline $\begin{array}{l}\text { I believe that Akaev in 2005 and Bakiev in 2010 used excessive force in attempting to suppress } \\
\text { protesters, respectively. }\end{array}$ & 246 & 24.5 \\
\hline $\begin{array}{l}\text { I do not believe that either Akaev in 2005 or Bakiev in 2010 used excessive force in attempting to } \\
\text { suppress protesters, respectively. }\end{array}$ & 114 \\
\hline $\begin{array}{l}\text { I have no opinion on this issue. } \\
\text { Hard to say. }\end{array}$ & 11.4 \\
\hline $\mathrm{N}$ & 3 \\
\hline
\end{tabular}

Table 4. Contemporary popular attitudes on the justification of leaders to use force in 2005 and 2010 in Kyrgyzstan.

\begin{tabular}{lcc}
\hline Responses & Frequency & Percent \\
\hline $\begin{array}{l}\text { I believe that Akaev was justified to employ force against protesters in 2005 but Bakiev was not } \\
\text { justified to employ force against protesters in 2010. }\end{array}$ & 176 & 17.5 \\
\hline $\begin{array}{l}\text { I believe that Bakiev was justified to employ force against protesters in 2010 but Akaev was not } \\
\text { justified to employ force against protesters in 2005. }\end{array}$ & 73 & 7.3 \\
\hline $\begin{array}{l}\text { I believe that Akaev in 2005 and Bakiev in 2010 were justified to employ force against } \\
\text { protesters, respectively. }\end{array}$ & 139 \\
\hline $\begin{array}{l}\text { I do not believe that either Akaev in } 2005 \text { or Bakiev in 2010 were justified to employ force } \\
\text { against protesters, respectively }\end{array}$ & 361 \\
\hline I have no opinion on this issue. & 35.9 \\
\hline Hard to say. & 248 \\
\hline N & 6 & 24.8 \\
\hline
\end{tabular}

Table 5. Contemporary popular attitudes on Akaev's and Bakiev's responsibility for Kyrgyzstan's troubles today.

\begin{tabular}{lrc}
\hline Responses & Frequency & Percent \\
\hline I believe that Akaev is largely to blame for the troubles facing the country today. & 45 & 4.5 \\
\hline I believe that Bakiev is largely to blame for the troubles facing the country today. & 104 & 10.4 \\
\hline $\begin{array}{l}\text { I believe that Akaev and Bakiev are both largely to blame for the troubles } \\
\text { facing the country today. }\end{array}$ & 534 & 53.2 \\
\hline $\begin{array}{l}\text { I do not believe that either Akaev or Bakiev is largely to blame for the } \\
\text { troubles facing the country today. }\end{array}$ & 151 \\
\hline $\begin{array}{l}\text { I have no opinion on this issue. } \\
\text { Hard to say. }\end{array}$ & 167 \\
\hline Refusal. & 2 \\
\hline $\mathrm{N}$ & 15.0 \\
\hline
\end{tabular}


concerning perceptions of corruption with regards to presidential administrations since Kyrgyzstan's attainment of independence (Akaev, Bakiev, Otunbaeva, and Atambaev), a near majority (49 percent) opined that all of these administrations are corrupt (see table 6). However, in observing presidential administrations separately, Bakiev garnered the highest frequencies ( 22 percent). ${ }^{12}$ Kyrgyzstanis do not harbor feelings of nostalgia for Akaev or Bakiev either. Upon being asked, approximately 58 percent stated that they did not wish to return to the time when Akaev was in power (see table 7). ${ }^{13}$ An even more substantial percentage (73 percent) professed a disinterest in returning to the time when Bakiev presided over Kyrgyzstan (see table 8$)^{1}{ }^{1}$

Over the past several decades since the Soviet collapse Kyrgyzstan's "non-Asian non-Muslim" peoples have emigrated elsewhere, thus leaving the country with a growing Kyrgyz population and a substantial Uzbek minority (Wachtel 2013, 974). However, it is often stated that the country suffers from a north-south divide with political implications for Kyrgyzstanis. In analyzing the dynamics of this phenomenon, Maxim Ryabkov $(2008,309,313)$ interestingly argues that popular support for Kyrgyzstan's political institutions is substantially stronger in the south in comparison to the north, and although the divide may flourish on account of competing regional elites the nature of the "north-south cleavage" is "intra-ethnic" and rather nuanced. Generally speaking, the north "refuses support to political institutions and personalities ... and exhibits a high degree of alienation from politics"

Table 6. Contemporary popular attitudes on corruption within the presidential administrations of Kyrgyzstan.

\begin{tabular}{lrr}
\hline Responses & Frequency & Percent \\
\hline Akaev administration. & 63 & 6.2 \\
\hline Bakiev administration. & 220 & 21.9 \\
\hline Otunbaeva administration. & 20 & 2.0 \\
\hline Atambaev administration. & 53 & 5.3 \\
\hline I believe that all of these presidential administrations are very corrupt. & 496 & 49.4 \\
\hline I do not believe that any of these presidential administrations are corrupt. & 4 & 0.4 \\
\hline I have no opinion on this issue. & 148 & 14.8 \\
\hline Hard to say. & 1 & 0.1 \\
\hline $\mathrm{N}$ & 1004 & 100.0 \\
\hline
\end{tabular}

Table 7. Contemporary popular attitudes in Kyrgyzstan on a return to the Akaev era.

\begin{tabular}{lcc}
\hline Responses & Frequency & Percent \\
\hline I very much would like to return to the time in which Akaev was in power. & 84 & 148 \\
\hline I would like to return to the time in which Akaev was in power. & 188 & 14.7 \\
\hline I have no opinion on this issue. & 288 & 28.7 \\
\hline I would not like to return to the time in which Akaev was in power. & 290 & 28.9 \\
\hline I very much would not like to return to the time in which Akaev was in power. & 6 & 0.6 \\
\hline Hard to say. & \multirow{2}{*}{1004} & 100.0 \\
\hline $\mathrm{N}$ & & 28.7 \\
\hline
\end{tabular}


Table 8. Contemporary popular attitudes in Kyrgyzstan on a return to the Bakiev era.

\begin{tabular}{lcc}
\hline Responses & Frequency & Percent \\
\hline I very much would like to return to the time in which Bakiev was in power. & 63 & 6.3 \\
\hline I would like to return to the time in which Bakiev was in power. & 64 & 134 \\
\hline I have no opinion on this issue. & 214 & 13.4 \\
\hline I would not like to return to the time in which Bakiev was in power. & 523 & 52.1 \\
\hline I very much would not like to return to the time in which Bakiev was in power. & 4 & 0.4 \\
\hline Hard to say. & 2 & 0.2 \\
\hline Refusal. & 21004 & 100.0 \\
\hline $\mathrm{N}$ & & 2 \\
\hline
\end{tabular}

whereas the south is largely "loyal and optimistic" toward the institutions of the Kyrgyzstani state. Furthermore, Eugene Huskey and David Hill $(2013,246-248,259)$ contend that, in addition to a variety of other factors, "regionalism" or "a sense of identity with North or South" influences Kyrgyzstanis' support for political parties. In analyzing the 2010 parliamentary elections Huskey and Hill argue that regionalism partially explains why parties like Ata Jurt and Butun Kyrgyzstan (which did not win any seats due to a "fluke" electoral provision requiring the party's passage of a " $5 \%$ threshold of registered voters") fared well in southern districts while the Social Democratic Party of Kyrgyzstan and Ata Meken received high voter support in northern districts $(248-249,259)$.

So, are southerners predisposed to view the 2005 protests as legitimate and the 2010 protests as illegitimate, as well as defend the Bakiev administration's resort to forceful measures? And what about a popular support base for Akaev among northerners? Are such Kyrgyzstanis more likely to view the 2005 protests as illegitimate and the 2010 protests as legitimate, as well as express stronger condemnation of Bakiev's attempted crackdown? Upon grouping southern regions (Jalal-Abad region, Osh region, Osh city, and Batken region) and northern regions (Chuy region, Bishkek city, Naryn region, Issyk Kul region, and Talas region) together, cross tabulations were conducted according to provincial location and (1) popular attitudes toward the legitimacy of the 2005 and 2010 protests; (2) popular attitudes on whether Akaev and/or Bakiev utilized "excessive force" in response to the protests against their rule; and (3) popular attitudes on whether Akaev and/or Bakiev had any cause to employ forceful measures. Interestingly, a large portion of southerners (59 percent in Osh region; 54 percent in Osh city; 48 percent in Batken region; and 57 percent in Jalal-Abad region) view both the 2005 and 2010 protests as illegitimate or do not care to voice their opinion. ${ }^{15}$ Furthermore, in looking at the south, only in Batken region did more survey respondents view both the 2005 and 2010 protests as legitimate in comparison to respondents who viewed both protests as illegitimate. Moreover, a considerable amount in Osh region (15 percent) and Jalal-Abad region (15 percent) felt that the mass protests against Akaev (and not the mass protests against Bakiev) were legitimate (see table 9). This is important because Bakiev is originally from the JalalAbad region while Akaev hails from the Chuy region in the north. In contrast, a majority or plurality of respondents within the northern regions opined that both the 2005 and 2010 protests were legitimate (see table 9). Southerners though are not in a state of denial with regards to Bakiev's resort to forceful measures in April 2010. Accordingly, a plurality in each southern region (except for Batken region) opined that Bakiev in 2010 (and not Akaev in 2005) had used "excessive force" against mass protesters. ${ }^{16}$ Moreover, a majority in all but one northern region (Talas region) stated that Bakiev in 2010 (and not Akaev in 2005) had used "excessive force" (see table 10). Lastly, with the exception of the Osh and Batken regions, a plurality everywhere else stated that neither Akaev in 2005 nor Bakiev in 2010 was justified to resort to employing force against mass protesters. ${ }^{17}$ Slightly 
Table 9. Cross tabulations.

\begin{tabular}{|c|c|c|c|c|c|c|c|c|c|c|c|}
\hline & & \multicolumn{9}{|c|}{ Question: Could you please state where you reside in Kyrgyzstan today? } & \multirow[b]{2}{*}{ Total } \\
\hline & & $\begin{array}{l}\text { Osh } \\
\text { Region }\end{array}$ & $\begin{array}{l}\text { Osh } \\
\text { City }\end{array}$ & $\begin{array}{l}\text { Batken } \\
\text { Region }\end{array}$ & $\begin{array}{l}\text { Jalal-Abad } \\
\text { Region }\end{array}$ & $\begin{array}{l}\text { Chuy } \\
\text { Region }\end{array}$ & $\begin{array}{l}\text { Naryn } \\
\text { Region }\end{array}$ & $\begin{array}{l}\text { Talas } \\
\text { Region }\end{array}$ & $\begin{array}{l}\text { Issyk-Kul } \\
\text { Region }\end{array}$ & $\begin{array}{c}\text { Bishkek } \\
\text { City }\end{array}$ & \\
\hline \multirow{7}{*}{$\begin{array}{l}\text { Question: Some people believe } \\
\text { that the mass protests against } \\
\text { President Askar Akaev's rule } \\
\text { were legitimate, while others } \\
\text { do not. Some people also } \\
\text { believe that the mass protests } \\
\text { against President Kurmanbek } \\
\text { Bakiev's rule were legitimate, } \\
\text { while others do not. In your } \\
\text { opinion, do you believe that } \\
\text { the mass protests against } \\
\text { President Akaev's rule in } 2005 \\
\text { as well as President Bakiev's } \\
\text { rule in } 2010 \text { were legitimate? }\end{array}$} & $\begin{array}{l}\text { I believe that the mass protests } \\
\text { against Akaev's rule were } \\
\text { legitimate in nature but the } \\
\text { mass protests against Bakiev's } \\
\text { rule were illegitimate in nature. }\end{array}$ & 28 & 3 & 6 & 27 & 9 & 8 & 2 & 2 & 16 & 101 \\
\hline & $\begin{array}{l}\text { I believe that the mass protests } \\
\text { against Bakiev's rule were } \\
\text { legitimate in nature but the } \\
\text { mass protests against Akaev's } \\
\text { rule were illegitimate in nature. }\end{array}$ & 10 & 6 & 6 & 14 & 11 & 1 & 2 & 9 & 23 & 82 \\
\hline & $\begin{array}{l}\text { I believe that the mass protests } \\
\text { against both Akaev's rule and } \\
\text { Bakiev's rule were legitimate in } \\
\text { nature. }\end{array}$ & 38 & 14 & 29 & 35 & 63 & 23 & 24 & 38 & 79 & 343 \\
\hline & $\begin{array}{l}\text { I believe that the mass protests } \\
\text { against both Akaev's rule and } \\
\text { Bakiev's rule were illegitimate } \\
\text { in nature. }\end{array}$ & 60 & 19 & 17 & 44 & 45 & 8 & 8 & 17 & 40 & 258 \\
\hline & I have no opinion on this issue. & 52 & 8 & 21 & 58 & 32 & 1 & 5 & 14 & 19 & 210 \\
\hline & Hard to say. & 3 & 0 & 1 & 1 & 1 & 0 & 0 & 0 & 2 & 8 \\
\hline & Refusal. & 0 & 0 & 0 & 0 & 0 & 0 & 0 & 0 & 1 & 1 \\
\hline \multicolumn{2}{|c|}{$\mathrm{N}$} & 191 & 50 & 80 & 179 & 161 & 41 & 41 & 80 & 180 & 1003 \\
\hline
\end{tabular}


Table 10. Cross tabulations.

\begin{tabular}{|c|c|c|c|c|c|c|c|c|c|c|c|}
\hline & & \multicolumn{9}{|c|}{ Question: Could you please state where you reside in Kyrgyzstan today? } & \multirow[b]{2}{*}{ Total } \\
\hline & & $\begin{array}{l}\text { Osh } \\
\text { Region }\end{array}$ & $\begin{array}{l}\text { Osh } \\
\text { City }\end{array}$ & $\begin{array}{l}\text { Batken } \\
\text { Region }\end{array}$ & $\begin{array}{l}\text { Jalal-Abad } \\
\text { Region }\end{array}$ & $\begin{array}{l}\text { Chuy } \\
\text { Region }\end{array}$ & $\begin{array}{l}\text { Naryn } \\
\text { Region }\end{array}$ & $\begin{array}{l}\text { Talas } \\
\text { Region }\end{array}$ & $\begin{array}{l}\text { Issyk-Kul } \\
\text { Region }\end{array}$ & $\begin{array}{l}\text { Bishkek } \\
\text { City }\end{array}$ & \\
\hline \multirow{7}{*}{$\begin{array}{l}\text { Question: Could you please } \\
\text { state your opinion on } \\
\text { whether you feel that } \\
\text { President Askar Akaev or } \\
\text { President Kurmanbek } \\
\text { Bakiev used excessive force } \\
\text { in attempting to suppress } \\
\text { the mass protests in } 2005 \\
\text { and } 2010 \text {, respectively? }\end{array}$} & $\begin{array}{l}\text { I believe that Akaev used excessive } \\
\text { force in attempting to suppress } \\
\text { protesters in } 2005 \text { but Bakiev did } \\
\text { not use excessive force in } \\
\text { attempting to suppress protesters } \\
\text { in } 2010 .\end{array}$ & 17 & 4 & 14 & 16 & 2 & 0 & 0 & 2 & 2 & 57 \\
\hline & $\begin{array}{l}\text { I believe that Bakiev used excessive } \\
\text { force in attempting to suppress } \\
\text { protesters in } 2010 \text { but Akaev did } \\
\text { not use excessive force in } \\
\text { attempting to suppress protesters } \\
\text { in } 2005 .\end{array}$ & 54 & 19 & 18 & 55 & 98 & 22 & 16 & 48 & 96 & 426 \\
\hline & $\begin{array}{l}\text { I believe that Akaev in } 2005 \text { and } \\
\text { Bakiev in } 2010 \text { used excessive } \\
\text { force in attempting to suppress } \\
\text { protesters, respectively. }\end{array}$ & 34 & 14 & 16 & 43 & 38 & 10 & 19 & 21 & 51 & 246 \\
\hline & $\begin{array}{l}\text { I do not believe that either Akaev in } \\
2005 \text { or Bakiev in } 2010 \text { used } \\
\text { excessive force in attempting to } \\
\text { suppress protesters, respectively. }\end{array}$ & 37 & 5 & 11 & 34 & 7 & 6 & 1 & 0 & 12 & 113 \\
\hline & I have no opinion on this issue. & 47 & 7 & 21 & 32 & 17 & 1 & 4 & 8 & 19 & 156 \\
\hline & Hard to say. & 2 & 1 & 0 & 0 & 0 & 0 & 0 & 1 & 0 & 4 \\
\hline & $\mathrm{N}$ & 191 & 50 & 80 & 180 & 162 & 39 & 40 & 80 & 180 & 1002 \\
\hline
\end{tabular}


more respondents in the Osh and Jalal-Abad regions and in Osh city also felt that Akaev in 2005 (and not Bakiev in 2010) was justified to employ force to quell mass protesters, as opposed to those respondents who opined that Bakiev in 2010 (and not Akaev in 2005) was justified to do so (see table 11). Taken together, although the north-south divide in Kyrgyzstan is revealed somewhat when assessing popular opinions regarding the 2005 and 2010 protests in the computer-assisted telephone interviewing survey, southerners do not adamantly stand behind Bakiev.

In summary, although both former presidents are seemingly despised by a majority of Kyrgyzstanis today, survey results indicate that Bakiev is disliked considerably more so than Akaev. Of course, the fact that Bakiev was in power more recently than Akaev may explain the greater degree of discontent expressed toward the former. However, in regard to the aforementioned survey question concerning popular attitudes on whether Akaev or Bakiev is largely responsible for "the troubles facing the country today" only 10 percent labeled Bakiev as being solely at fault (see table 5). This is a significant finding, for if the basis of popular hatred for Bakiev lies purely with the former president's governing style over the course of his tenure, then we would expect to see many more survey respondents select this answer as a response. As such, a strong basis for such hatred plausibly rests with Bakiev's employment of violence in April 2010. It is important, however, to uncover the manner in which bystanders (ordinary Kyrgyzstanis who did not participate in the mass protests) or members of the "non-mob" (for those inclined to view the so-called revolutionaries who toppled Akaev and Bakiev as affiliates of an uncivil assembly) perceived the 2005 and 2010 uprisings and ensuing responses by the Akaev and Bakiev administrations. In what follows, I analyze the opinions of Kyrgyzstanis surveyed in 2016 who reportedly did not participate in the two most seminal political events in their country's recent history.

\section{Mass Mentalities on Protests and Crackdowns in Kyrgyzstan}

The 2010 protests, which originally began in the early spring, were tinged by a degree of violence, such as when government buildings were stormed in Talas and other cities and mass protesters confiscated armored vehicles and firearms from police in Bishkek. Arguably, President Bakiev was therefore justified in resorting to a minor show of force to restore order. However, the refusal of Bakiev and Prime Minister Daniar Usenov to concede to the demands of several thousand protesters in Bishkek by meeting with them on April 7, and instead responding with a demonstration of lethal force when mass protesters sought to breach the presidential building, aggravated relations between the government and citizens. Several days later, Bakiev fled the country, initially to Kazakhstan, where he issued his resignation, and then onto Belarus whereupon arriving he refused to abdicate (Nichol 2010, 2-5).

Did the mass protesters who participated in the overthrow of Bakiev amount to an unruly mob? As previously stated, since protesters likely view themselves as legitimate while the government perceives and depicts them as illegitimate, it can be difficult to make an objective call on this issue. It is clear that (1) the mass protesters had reason to be upset with the Kyrgyzstani government under Bakiev's stewardship in light of the utility price hikes in addition to other concerns, most notably political corruption (Nichol 2010,2); and (2) violent acts were carried out by some of the mass protesters, thereby debatably justifying Bakiev's resort to forceful measures to a degree. That said, in analyzing several of the aforementioned survey questions via cross tabulation, several findings stand out. It is worth emphasizing that approximately 80 percent of all respondents in the 2016 computer-assisted telephone interviewing survey did not participate in either the 2005 mass protests against Akaev or the 2010 mass protests against Bakiev.

Bearing this in mind, cross tabulations reveal that approximately 32 percent of the nonparticipants of the 2005 and 2010 protests surveyed believed that both the mass protests against Akaev in 2005 and Bakiev in 2010 were legitimate (see table 12). Such a finding indicates that Kyrgyzstan's two revolutions lacked widespread social backing. Nevertheless, only about 14 percent of the nonparticipants of the 2005 and 2010 protests surveyed felt that the Kyrgyzstani government was justified to resort to forceful measures in both 2005 and 2010 (see table 13). In summary, the 
Table 11. Cross tabulations.

\begin{tabular}{|c|c|c|c|c|c|c|c|c|c|c|c|}
\hline & & \multicolumn{9}{|c|}{ Question: Could you please state where you reside in Kyrgyzstan today? } & \multirow[b]{2}{*}{ Total } \\
\hline & & $\begin{array}{l}\text { Osh } \\
\text { Region }\end{array}$ & $\begin{array}{l}\text { Osh } \\
\text { city }\end{array}$ & $\begin{array}{l}\text { Batken } \\
\text { Region }\end{array}$ & $\begin{array}{c}\text { Jalal-Abad } \\
\text { Region }\end{array}$ & $\begin{array}{l}\text { Chuy } \\
\text { region }\end{array}$ & $\begin{array}{l}\text { Naryn } \\
\text { Region }\end{array}$ & $\begin{array}{l}\text { Talas } \\
\text { Region }\end{array}$ & $\begin{array}{l}\text { Issyk-Kul } \\
\text { Region }\end{array}$ & $\begin{array}{c}\text { Bishkek } \\
\text { City }\end{array}$ & \\
\hline \multirow{6}{*}{$\begin{array}{l}\text { Question: Could you please } \\
\text { state your opinion on } \\
\text { whether you feel that } \\
\text { President Askar Akaev was } \\
\text { justified or not to employ } \\
\text { force against protesters } \\
\text { during the } 2005 \text { revolution } \\
\text { as well as whether you feel } \\
\text { that President Kurmanbek } \\
\text { Bakiev was justified or not } \\
\text { to employ force against } \\
\text { protesters during the } 2010 \\
\text { revolution? }\end{array}$} & $\begin{array}{l}\text { I believe that Akaev was justified } \\
\text { to employ force against } \\
\text { protesters in } 2005 \text { but Bakiev } \\
\text { was not justified to employ } \\
\text { force against protesters in } \\
2010 .\end{array}$ & 22 & 5 & 8 & 25 & 39 & 14 & 9 & 13 & 43 & 178 \\
\hline & $\begin{array}{l}\text { I believe that Bakiev was justified } \\
\text { to employ force against } \\
\text { protesters in } 2010 \text { but Akaev } \\
\text { was not justified to employ } \\
\text { force against protesters in } \\
2005 .\end{array}$ & 19 & 3 & 10 & 15 & 9 & 0 & 3 & 3 & 11 & 73 \\
\hline & $\begin{array}{l}\text { I believe that Akaev in } 2005 \text { and } \\
\text { Bakiev in } 2010 \text { were justified to } \\
\text { employ force against } \\
\text { protesters, respectively. }\end{array}$ & 28 & 11 & 19 & 35 & 9 & 6 & 6 & 9 & 15 & 138 \\
\hline & $\begin{array}{l}\text { I do not believe that either Akaev } \\
\text { in } 2005 \text { or Bakiev in } 2010 \text { were } \\
\text { justified to employ force } \\
\text { against protesters, } \\
\text { respectively }\end{array}$ & 55 & 22 & 20 & 54 & 72 & 18 & 14 & 35 & 71 & 361 \\
\hline & I have no opinion on this issue. & 65 & 9 & 23 & 49 & 31 & 3 & 9 & 19 & 40 & 248 \\
\hline & Hard to say. & 2 & 1 & 0 & 3 & 1 & 0 & 0 & 0 & 0 & 7 \\
\hline \multicolumn{2}{|c|}{$\mathrm{N}$} & 191 & 51 & 80 & 181 & 161 & 41 & 41 & 79 & 180 & 1005 \\
\hline
\end{tabular}




\begin{tabular}{|c|c|c|c|c|c|c|c|}
\hline & & \multicolumn{5}{|c|}{$\begin{array}{c}\text { Question: Could you please state whether you participated in the mass protests in } 2005 \text { which led to } \\
\text { the overthrow of Kyrgyzstani President Askar Akaev or the mass protests in } 2010 \text { which led to the } \\
\text { overthrow of Kyrgyzstani President Kurmanbek Bakiev? }\end{array}$} & \multirow[b]{2}{*}{ Total } \\
\hline & & $\begin{array}{l}\text { I participated in } \\
\text { the } 2005 \text { protests } \\
\text { but I did not } \\
\text { participate in the } \\
2010 \text { protests. }\end{array}$ & $\begin{array}{l}\text { I participated in } \\
\text { the } 2010 \text { protests } \\
\text { but I did not } \\
\text { participate in the } \\
2005 \text { protests. }\end{array}$ & $\begin{array}{l}\text { I participated } \\
\text { in both the } \\
2005 \text { protests } \\
\text { and the } 2010 \\
\text { protests. }\end{array}$ & $\begin{array}{l}\text { I did not } \\
\text { participate in } \\
\text { either the } 2005 \\
\text { protests or the } \\
2010 \text { protests. }\end{array}$ & Hard to say. & \\
\hline \multirow{8}{*}{$\begin{array}{l}\text { Question: Some people } \\
\text { believe that the mass } \\
\text { protests against } \\
\text { President Askar Akaev's } \\
\text { rule were legitimate, } \\
\text { while others do not. } \\
\text { Some people also believe } \\
\text { that the mass protests } \\
\text { against President } \\
\text { Kurmanbek Bakiev's rule } \\
\text { were legitimate, while } \\
\text { others do not. In your } \\
\text { opinion, do you believe } \\
\text { that the mass protests } \\
\text { against President } \\
\text { Akaev's rule in } 2005 \text { as } \\
\text { well as President } \\
\text { Bakiev's rule in } 2010 \text { were } \\
\text { legitimate? }\end{array}$} & $\begin{array}{l}\text { I believe that the mass protests } \\
\text { against Akaev's rule were } \\
\text { legitimate in nature but the mass } \\
\text { protests against Bakiev's rule } \\
\text { were illegitimate in nature. }\end{array}$ & 19 & 4 & 8 & 70 & 0 & 101 \\
\hline & $\begin{array}{l}\text { I believe that the mass protests } \\
\text { against Bakiev's rule were } \\
\text { legitimate in nature but the mass } \\
\text { protests against Akaev's rule } \\
\text { were illegitimate in nature. }\end{array}$ & 6 & 9 & 6 & 61 & 0 & 82 \\
\hline & $\begin{array}{l}\text { I believe that the mass protests } \\
\text { against both Akaev's rule and } \\
\text { Bakiev's rule were legitimate in } \\
\text { nature. }\end{array}$ & 19 & 19 & 48 & 255 & 2 & 343 \\
\hline & $\begin{array}{l}\text { I believe that the mass protests } \\
\text { against both Akaev's rule and } \\
\text { Bakiev's rule were illegitimate in } \\
\text { nature. }\end{array}$ & 10 & 20 & 14 & 214 & 1 & 259 \\
\hline & I have no opinion on this issue. & 3 & 8 & 7 & 192 & 0 & 210 \\
\hline & Hard to say. & 1 & 0 & 0 & 6 & 0 & 7 \\
\hline & Refusal. & 0 & 0 & 0 & 1 & 0 & 1 \\
\hline & $\mathrm{N}$ & 58 & 60 & 83 & 799 & 3 & 1003 \\
\hline
\end{tabular}




\begin{tabular}{|c|c|c|c|c|c|c|c|}
\hline & & \multicolumn{5}{|c|}{$\begin{array}{l}\text { Question: Could you please state whether you participated in the mass protests in } 2005 \text { which led to } \\
\text { the overthrow of Kyrgyzstani President Askar Akaev or the mass protests in } 2010 \text { which led to the } \\
\text { overthrow of Kyrgyzstani President Kurmanbek Bakiev? }\end{array}$} & \multirow[b]{2}{*}{ Total } \\
\hline & & $\begin{array}{l}\text { I participated in } \\
\text { the } 2005 \text { protests } \\
\text { but I did not } \\
\text { participate in the } \\
2010 \text { protests. }\end{array}$ & $\begin{array}{l}\text { I participated in } \\
\text { the } 2010 \text { protests } \\
\text { but I did not } \\
\text { participate in the } \\
2005 \text { protests. }\end{array}$ & $\begin{array}{l}\text { I participated } \\
\text { in both the } \\
2005 \text { protests } \\
\text { and the } 2010 \\
\text { protests. }\end{array}$ & $\begin{array}{l}\text { I did not } \\
\text { participate in } \\
\text { either the } 2005 \\
\text { protests or the } \\
2010 \text { protests. }\end{array}$ & Hard to say. & \\
\hline \multirow{7}{*}{$\begin{array}{l}\text { Question: Could you please } \\
\text { state your opinion on } \\
\text { whether you feel that } \\
\text { President Askar Akaev } \\
\text { was justified or not to } \\
\text { employ force against } \\
\text { protesters during the } \\
2005 \text { revolution as well as } \\
\text { whether you feel that } \\
\text { President Kurmanbek } \\
\text { Bakiev was justified or } \\
\text { not to employ force } \\
\text { against protesters during } \\
\text { the } 2010 \text { revolution? }\end{array}$} & $\begin{array}{l}\text { I believe that Akaev was justified to } \\
\text { employ force against protesters } \\
\text { in } 2005 \text { but Bakiev was not } \\
\text { justified to employ force against } \\
\text { protesters in } 2010 \text {. }\end{array}$ & 9 & 13 & 14 & 140 & 0 & 176 \\
\hline & $\begin{array}{l}\text { I believe that Bakiev was justified to } \\
\text { employ force against protesters } \\
\text { in } 2010 \text { but Akaev was not } \\
\text { justified to employ force against } \\
\text { protesters in } 2005 \text {. }\end{array}$ & 18 & 8 & 7 & 40 & 0 & 73 \\
\hline & $\begin{array}{l}\text { I believe that Akaev in } 2005 \text { and } \\
\text { Bakiev in } 2010 \text { were justified to } \\
\text { employ force against protesters, } \\
\text { respectively. }\end{array}$ & 4 & 10 & 13 & 111 & 0 & 138 \\
\hline & $\begin{array}{l}\text { I do not believe that either Akaev in } \\
2005 \text { or Bakiev in } 2010 \text { were } \\
\text { justified to employ force against } \\
\text { protesters, respectively }\end{array}$ & 18 & 20 & 37 & 286 & 0 & 361 \\
\hline & I have no opinion on this issue. & 6 & 10 & 11 & 219 & 2 & 248 \\
\hline & Hard to say. & 2 & 0 & 1 & 4 & 0 & 7 \\
\hline & $\mathrm{N}$ & 57 & 61 & 83 & 800 & 2 & 1003 \\
\hline
\end{tabular}




\begin{tabular}{|c|c|c|c|c|c|c|c|}
\hline & & \multicolumn{5}{|c|}{$\begin{array}{l}\text { Question: Could you please state whether you participated in the mass protests in } 2005 \text { which led to } \\
\text { the overthrow of Kyrgyzstani President Askar Akaev or the mass protests in } 2010 \text { which led to the } \\
\text { overthrow of Kyrgyzstani President Kurmanbek Bakiev? }\end{array}$} & \multirow[b]{2}{*}{ Total } \\
\hline & & $\begin{array}{l}\text { I participated in the } \\
2005 \text { protests but I did } \\
\text { not participate in the } \\
2010 \text { protests. }\end{array}$ & $\begin{array}{l}\text { I participated in } \\
\text { the } 2010 \text { protests } \\
\text { but I did not } \\
\text { participate in the } \\
2005 \text { protests. }\end{array}$ & $\begin{array}{l}\text { I participated } \\
\text { in both the } \\
2005 \text { protests } \\
\text { and the } 2010 \\
\text { protests. }\end{array}$ & $\begin{array}{l}\text { I did not } \\
\text { participate in } \\
\text { either the } 2005 \\
\text { protests or the } \\
2010 \text { protests. }\end{array}$ & Hard to say. & \\
\hline \multirow{7}{*}{$\begin{array}{l}\text { Question: Could you } \\
\text { please state your } \\
\text { opinion on whether } \\
\text { you feel that } \\
\text { President Askar } \\
\text { Akaev or President } \\
\text { Kurmanbek Bakiev } \\
\text { used excessive force } \\
\text { in attempting to } \\
\text { suppress the mass } \\
\text { protests in } 2005 \text { and } \\
2010 \text {, respectively? }\end{array}$} & $\begin{array}{l}\text { I believe that Akaev used excessive } \\
\text { force in attempting to suppress } \\
\text { protesters in } 2005 \text { but Bakiev did } \\
\text { not use excessive force in } \\
\text { attempting to suppress protesters } \\
\text { in } 2010 .\end{array}$ & 15 & 2 & 2 & 39 & 0 & 58 \\
\hline & $\begin{array}{l}\text { I believe that Bakiev used excessive } \\
\text { force in attempting to suppress } \\
\text { protesters in } 2010 \text { but Akaev did } \\
\text { not use excessive force in } \\
\text { attempting to suppress protesters } \\
\text { in } 2005 .\end{array}$ & 13 & 36 & 37 & 339 & 1 & 426 \\
\hline & $\begin{array}{l}\text { I believe that Akaev in } 2005 \text { and } \\
\text { Bakiev in } 2010 \text { used excessive force } \\
\text { in attempting to suppress } \\
\text { protesters, respectively. }\end{array}$ & 20 & 13 & 25 & 187 & 0 & 245 \\
\hline & $\begin{array}{l}\text { I do not believe that either Akaev in } \\
2005 \text { or Bakiev in } 2010 \text { used } \\
\text { excessive force in attempting to } \\
\text { suppress protesters, respectively. }\end{array}$ & 6 & 4 & 12 & 93 & 0 & 115 \\
\hline & I have no opinion on this issue. & 2 & 6 & 7 & 139 & 2 & 156 \\
\hline & Hard to say. & 0 & 0 & 1 & 2 & 0 & 3 \\
\hline & $\mathrm{N}$ & 56 & 61 & 84 & 799 & 3 & 1003 \\
\hline
\end{tabular}


research findings highlighted in this article indicate that a nondemocratic leader's decision to resort to violence to stifle mass protests can cause his or her political legitimacy to crumble, even if the mass protests do not command widespread popular support.

It has been argued that a government's use of repression against civilians can "backfire," in that coercive state actions occasionally mobilize people, thereby setting the stage for turning an opposition into a social movement. Acts of repression can serve as "transformative events," pending that the wider population views the state's repressive tactics as "unjust" and the occurrence of such an "event" is disseminated to "receptive audiences" (Hess and Martin 2006). In analyzing the 2016 computer-assisted telephone interviewing survey results via cross tabulations, it is quite evident that Bakiev's ill-fated crackdown was poorly received by Kyrgyzstani citizens. In regards to respondents who admitted to participating in both the 2005 and 2010 protests, a plurality (44 percent) felt that Bakiev (and not Akaev) had used "excessive force" against mass protesters, while 30 percent opined that both former presidents were guilty of resorting to such measures. In regards to the nonparticipants of the 2005 and 2010 protests, a strong plurality (42 percent) similarly felt that Bakiev (and not Akaev) had used "excessive force" (see table 14). ${ }^{18}$ In turn, the bulk of respondents who admitted to participating in both the 2005 and 2010 protests (45 percent) as well as a considerable amount of non-participants in both of these protests (36 percent) stated that neither Akaev nor Bakiev had justification to resort to forceful measures to quell the mass protests. Still, 18 percent of the non-participants in the 2005 and 2010 protests opined that Akaev had justification to resort to force in 2005 (while Bakiev did not in 2010). This considerably outweighs the 5 percent of non-participants in the 2005 and 2010 protests who believed that Bakiev had just cause in 2010 (and not Akaev in 2005) to use force (see table 13). Such results lend support to the notion that Bakiev's crackdown was considered to be a heinous act.

\section{Conclusion}

My research findings thus tentatively argue that Kyrgyzstanis today evaluate the Bakiev administration more negatively than they do the Akaev administration due to the former's use of violence in April 2010. It is worth noting that the 2016 computer-assisted telephone interviewing survey consists of 1,000 Kyrgyzstani respondents, thereby making it a challenge to generalize outside of this country. It is also important to highlight that additional field research (particularly in the form of interviews or focus groups) could further assess the causal link alleged within this article between Bakiev's 2010 crackdown and the generally widespread negative attitudes among Kyrgyzstani citizens toward his rule. However, academics may infer that nondemocratic leaders who attempt to carry out vulgar acts against mass protesters suffer political-reputational costs for doing so. In other words, the employment of state-sponsored violence against a relatively small portion of a country's populace amounts to an act of desperation on behalf of the government in the eyes of the wider public, thereby resulting in the disintegration of a leader's legitimate claim to authority. Granted, it can be argued that Bakiev's legitimacy had already considerably deteriorated on account of his heavy-handed governing style prior to the events of April 2010. Yet the substantial variation in popular opinions regarding Akaev and Bakiev's responses to mass protesters again highlights the importance of the failed 2010 crackdown. Survey data results clearly show that Bakiev's resort to brute force was not well received by the public.

Overall, a government's resort to forceful measures to quell mass protesters seemingly exhibits a considerable negative effect. Other scholars who have studied the 2014 Euromaidan revolution in Ukraine (which spurred the toppling of President Yanukovych) argue that the brutality inflicted upon civilians in Kyiv during the early stages of the protests significantly undermined the legitimacy of the government and energized a movement (Kudelia 2014, 28-29; Onuch 2014, 45-46). The key difference in Kyrgyzstan is that once Bakiev resorted to brute force tactics to cling to power, efforts to restore the status quo failed instantaneously, thereby displaying the sheer weakness and hollow nature of the ruling regime. Simply put, Bakiev's forceful response to the mass protesters never 
materialized into a "transformative event" and it did not have to since the regime collapsed immediately following Bakiev's ill-fated crackdown.

Crackdowns are risky endeavors, for if they fail then the result may be regime implosion, civil war, insurgency, foreign intervention, or some combination thereof. To be certain, crackdowns occasionally succeed in terms of suppressing social movements. For example, in May 2005, the Uzbekistani government violently dispersed an assembly in the city of Andijon in the wake of an armed jailbreak (Khalid 2007, 192-198), thereby effectively terminating any potential challenge to President Islam Karimov's rule. In December 2011, the Kazakhstani government also suppressed a worker strike which had turned violent in the city of Zhanaozen (McGlinchey 2013, 6-7). In these instances, the governments in question halted the spread of mass protests by resorting to a display of brute force in the epicenters of mobilized social activity and denying citizens access to information thereafter about what had actually transpired. However, it stands to reason that because of the political-reputational costs involved, crackdowns should be instituted only as last resort measures in the interest of averting sociopolitical chaos. This is especially the case with highly personalist regimes like those across Central Asia. After all, once a nondemocratic government decides to institute a crackdown against mass protesters the legitimacy of the leader, which has been thoroughly cultivated over an extensive period of time, and the ruling regime is placed at stake and can be squandered. Hence, when facing mobilized masses, embattled nondemocratic leaders should refrain from employing brute force at the outset and instead strive to address popular concerns through peaceful dialogue and negotiations, in the hopes of preserving their own legitimacy, ensuring regime continuity, and averting their country's downward spiral.

Acknowledgments. I thank Nazarbayev University for awarding me a Social Policy Grant in furtherance of partial funding for the 2016 computer-assisted telephone interviewing survey, the results of which are highlighted in this article. I also thank my reviewers and colleagues who provided me with valuable feedback at the 2016 Central Eurasian Studies Society and 2017 Association of the Study of Nationalities conferences.

Financial Support. Partial funding for the 2016 Kyrgyzstan-based computer-assisted telephone interviewing survey was awarded by a Nazarbayev University Social Policy Grant. This source did not assume any role in the design or conduct of the survey research. I used this grant funding to contract with the BRIF Research Group to organize the survey and to attend academic conferences to present data findings.

Disclosure. The author has nothing to disclose.

\section{Notes}

1 Michael McFaul $(2005,18)$ does not include Kyrgyzstan's 2005 revolution in his analysis of the Color Revolutions.

2 The author retains proprietary rights to the 2016 survey data set. Surveying was conducted in Bishkek city, Osh city, Batken region, Jalal-Abad region, Chuy region, Naryn region, Talas region, Issyk-Kul region, and Osh region. Respondents were contacted via mobile telephones and underwent verbal recruitment and informed consent procedures in Russian or Kyrgyz language (approximately 10 percent opted to participate in the survey in Kyrgyz). All respondents were 30 years of age or older. Data results have been weighted according to a variable provided by the BRIF Research Group. With respect to the survey design, "Refusal" was not initially included in the listing of selectable responses to questions, so as to minimize its frequency. If respondents felt uncertain about how to respond to a question, interviewers provided "Refusal" for possible selection. "Refusal" was not provided for possible selection for designating residency. A survey question requesting to designate nationality reads, "Can you please state your nationality?" Respondents could select from "Kyrgyz," "Uzbek," "Russian," "Other," or "Refusal."

3 Approximately 80 percent of respondents did not participate in the 2005 protests against President Akaev or the 2010 protests against President Bakiev, while 6 percent admitted to participating in the 2005 protests, 6 percent admitted to participating in the 2010 protests, and 
8 percent admitted to participating in both protests. A survey question reads, "Could you please state whether you participated in the mass protests in 2005 that led to the overthrow of Kyrgyzstani president Askar Akaev or the mass protests in 2010 that led to the overthrow of Kyrgyzstani president Kurmanbek Bakiev?"

4 A survey question reads, "Some people believe that the mass protests against President Askar Akaev's rule were legitimate, while others do not. Some people also believe that the mass protests against President Kurmanbek Bakiev's rule were legitimate, while others do not. In your opinion, do you believe that the mass protests against President Akaev's rule in 2005 as well as President Bakiev's rule in 2010 were legitimate?"

5 Schatz $(2009,217)$ also argues that Akaev's declaration to not run for reelection amounted to a "major miscalculation."

6 See also Schatz $(2009,214)$.

7 See McGlinchey $(2011,100-108)$ for an overview of Bakiev's ruling style.

8 A survey question reads, "Some people believe that the mass protests against President Askar Akaev's rule were orchestrated or sponsored by foreign states, while others do not. Some people also believe that the mass protests against President Kurmanbek Bakiev's rule were orchestrated or sponsored by foreign states, while others do not. In your opinion, do you believe that the mass protests against President Akaev's rule in 2005 as well as President Bakiev's rule in 2010 were orchestrated or sponsored by foreign states?"

9 A survey question reads, "Could you please state your opinion on whether you feel that President Askar Akaev or President Kurmanbek Bakiev used excessive force in attempting to suppress the mass protests in 2005 and 2010, respectively?" Even though Akaev was unable or unwilling to institute a full-fledged crackdown against the protesters in 2005, a considerable portion of respondents (25 percent) nonetheless felt that both leaders resorted to methods deemed to be "excessive."

10 A survey question reads, "Could you please state your opinion on whether you feel that President Askar Akaev was justified or not to employ force against protesters during the 2005 revolution as well as whether you feel that President Kurmanbek Bakiev was justified or not to employ force against protesters during the 2010 revolution?"

11 A survey question reads, "Some people believe that Kyrgyzstan's former leaders are responsible for the various domestic problems facing the country today, while others do not. What do you think? Do you believe that either President Askar Akaev or President Kurmanbek Bakiev is largely responsible for Kyrgyzstan's problems today?"

12 A survey question reads, "Some people believe that corruption at the elite level in Kyrgyzstani politics is a widespread problem, while others do not. In your opinion, which Kyrgyzstani presidential administration is the most corrupt?"

13 A survey question reads, "Some people would like to return to the time in which President Askar Akaev governed over Kyrgyzstan, while others would not. If possible, would you prefer to return to the time in which President Akaev was in power?" In response, 29 percent stated that they "very much would not like to return to the time in which Akaev was in power."

14 A survey question reads, "Some people would like to return to the time in which President Kurmanbek Bakiev governed over Kyrgyzstan, while others would not. If possible, would you prefer to return to the time in which President Bakiev was in power?" In response, 52 percent stated that they "very much would not like to return to the time in which Bakiev was in power."

15 A considerable portion of survey respondents in each southern region though stated that both the 2005 and 2010 protests were legitimate (20 percent in Osh region; 28 percent in Osh city; 36 percent in Batken region; and 20 percent in Jalal-Abad region).

16 A plurality (26 percent) of survey respondents in Batken region did not give an opinion on this issue. 17 A plurality in the Osh (34 percent) and Batken (29 percent) regions did not give an opinion in response to this question.

18 In contrast, only 5 percent of non-participants of the 2005 and 2010 protests surveyed answered that Akaev (and not Bakiev) had used "excessive force" against protesters. 


\section{References}

Bunce, Valerie, and Sharon L. Wolchik. 2006. “Favorable Conditions and Electoral Revolutions.” Journal of Democracy 17 (4): 5-18. Bunce, Valerie, and Sharon L. Wolchik. 2009. "Getting Real about 'Real Causes.” Journal of Democracy 20 (1): 69-73.

Chenoweth, Erica, and Maria J. Stephan. 2014. “Drop Your Weapons: When and Why Civil Resistance Works.” Foreign Affairs 93 (4): 94-106.

Colaresi, Michael, and Sabine C. Carey. 2008. “To Kill or to Protect: Security Forces, Domestic Institutions, and Genocide.” Journal of Conflict Research 52 (1): 39-67.

Collier, Paul. 2009. “The Dictator's Handbook.” Foreign Policy 172: 146-149.

Collins, Kathleen. 2011. “Kyrgyzstan's Latest Revolution.” Journal of Democracy 22 (3): 150-164.

Cooley, Alexander. 2010. "Kyrgyzstan on the Brink." Current History 109 (729): 301-307.

Diamond, Larry. 1994. "Rethinking Civil Society: Toward Democratic Consolidation." Journal of Democracy 5 (3): 4-17.

Diamond, Larry. 2002. "Elections without Democracy: Thinking about Hybrid Regimes." Journal of Democracy 13 (2): 21-35.

Gandhi, Jennifer, and Adam Przeworski. 2007. "Authoritarian Institutions and the Survival of Autocrats." Comparative Political Studies 40 (11): 1279-1301.

Hale, Henry E. 2005. "Regime Cycles: Democracy, Autocracy, and Revolution in Post-Soviet Eurasia.” World Politics 58 (1): 133-165.

Hess, David, and Brian Martin. 2006. “Repression, Backfire, and the Theory of Transformative Events.” Mobilization 11 (2): 249-267.

Hill, Fiona, and Kevin Jones. 2006. “Fear of Democracy or Revolution: The Reaction to Andijon.” Washington Quarterly 29 (3): 111-125.

Huskey, Eugene, and David Hill. 2013. "Regionalism, Personalism, Ethnicity, and Violence: Parties and Voter Preference in the 2010 Parliamentary Election in Kyrgyzstan.” Post-Soviet Affairs 29 (3): 237-267.

Khalid, Adeeb. 2007. Islam after Communism: Religion and Politics in Central Asia. Berkeley: University of California Press. Kudelia, Serhiy. 2014. "The Maidan and Beyond: The House that Yanukovych Built." Journal of Democracy 25 (3): 19-34.

Levitsky, Steven, and Lucan A. Way. 2002. “The Rise of Competitive Authoritarianism.” Journal of Democracy 13 (2): 51-65.

Levitsky, Steven, and Lucan A. Way. 2010. Competitive Authoritarianism: Hybrid Regimes after the Cold War. New York: Cambridge University Press.

McFaul, Michael. 2005. "Transitions from Postcommunism.” Journal of Democracy 16 (3): 5-19.

McGlinchey, Eric. 2005. "The Making of Militants: The State and Islam in Central Asia." Comparative Studies of South Asia, Africa, and the Middle East 25 (3): 554-566.

McGlinchey, Eric. 2011. Chaos, Violence, Dynasty: Politics and Islam in Central Asia. Pittsburgh: University of Pittsburgh Press.

McGlinchey, Eric. 2013. "Violent Extremism and Insurgency in Kazakhstan: A Risk Assessment." Report for the United States Agency for International Development.

Nichol, Jim. 2010. “The April 2010 Coup in Kyrgyzstan and Its Aftermath: Context and Implications for U.S. Interests.” Report for the Congressional Research Service.

Onuch, Olga. 2014. “The Maidan and Beyond: Who Were the Protesters?" Journal of Democracy 25 (3): 44-51.

Radnitz, Scott. 2005. "Networks, Localism, and Mobilization in Aksy, Kyrgyzstan.” Central Asian Survey 24 (4): $405-424$.

Radnitz, Scott. 2006. "What Really Happened in Kyrgyzstan?” Journal of Democracy 17 (2): 132-146.

Ryabkov, Maxim. 2008. “The North-South Cleavage and Political Support in Kyrgyzstan.” Central Asian Survey 27 (3/4): $301-316$.

Schatz, Edward. 2009. “The Soft Authoritarian Tool Kit: Agenda-Setting Power in Kazakhstan and Kyrgyzstan." Comparative Politics 41 (2): 203-222.

Schedler, Andreas. 2010. “Authoritarianism's Last Line of Defense.” Journal of Democracy 21 (1): 69-80.

Smith, Benjamin. 2005. "Life of the Party: The Origins of Regime Breakdown and Persistence under Single-Party Rule." World Politics 57 (3): 421-451.

Wachtel, Andrew Baruch. 2013. “Kyrgyzstan between Democratization and Ethnic Tolerance.” Nationalities Papers 41 (6): 971-986.

Way, Lucan A. 2008. “The Real Causes of the Color Revolutions.” Journal of Democracy 19 (3): 55-69.

Wooden, Amanda E. 2014. "Kyrgyzstan's Dark Ages: Framing and the 2010 Hydroelectric Revolution.” Central Asian Survey 33 (4): 463-481. 